\title{
MELATIH PESERTA DIDIK DALAM BERPIKIR KRITIS MELALUI PROBLEM BASED LEARNING PADA SMA NEGERI 1 DAGANGAN
}

\author{
Farida Styaningrum $^{1 *}$, Elva Nuraina ${ }^{2}$, Wuri Cahyaning Pramusti ${ }^{3}$ \\ ${ }^{1 *}$ Universitas PGRI Madiun \\ faridastyaningrum@unipma.ac.id \\ ${ }^{2,3}$ Universitas PGRI Madiun \\ 2elvanuraina@unipma.ac.id, ${ }^{3}$ wuricahyaning2@gmail.com
}

\begin{abstract}
ABSTRAK
Kesulitan dalam menganalisis suatu kasus menjadi kendala bagi peserta didik SMA Negeri 1 Dagangan, khususnya kelas XI IPA 2 dalam belajar ekonomi. Peserta didik membutuhkan bimbingan dan arahan untuk berpikir secara kritis dalam menyelesaikan kasus ekonomi. Penggunaan model pembelajaran yang mengaktifkan peserta didik dapat dijadikan sebagai upaya melatih dalam berpikir kritis. Adanya kegiatan pengabdian masyarakat ini bertujuan untuk melatih kemampuan berpikir kritis peserta didik pada materi ekonomi melalui model pembelajaran Problem Based Learning. Kegiatan dilaksanakan melalui pendampingan dan pengarahan kepada peserta didik untuk berpikir kritis dalam mengidentifikasi masalah, melakukan analisis sampai menyimpulkan solusi penyelesaian masalah. Hasil kegiatan memperlihatkan bahwa peserta didik dengan pemikiran yang kritis mampu menyelesaikan kasus APBN pada materi ekonomi dengan perolehan nilai rata-rata 85,08. Melalui strategi dan teknik berpikir kritis, peserta didik mampu mengidentifikasi masalah, menganalisis dan memberikan solusi pada kasus APBN. Diharapkan setelah adanya kegiatan ini, guru bersedia menggunakan PBL sebagai model pembelajaran untuk meningkatkan kemampuan peserta didik dalam berpikir secara kritis.
\end{abstract}

Kata Kunci: berpikir kritis; Problem Based Learning; pembelajaran ekonomi

\begin{abstract}
Difficulty in analyzing a case becomes an obstacle for students at SMA Negeri 1 Dagangan, especially class XI IPA 2 in studying economics. Students need guidance and direction to think critically in solving economic cases. The use of learning models that activate students can be used as an effort to train students in critical thinking. The existence of this community service activity aims to train students' critical thinking skills on economic material through the Problem Based Learning learning model. Activities are carried out through mentoring and directing students to think critically in identifying problems, analyzing concluding solutions to problemsolving. The results of the activity show that students with critical thinking can solve APBN cases on economic material with an average score of 85.08. Through critical thinking strategies and techniques, students can identify problems, analyze and provide solutions in APBN cases. It is hoped that after this activity, teachers are willing to use Problem Based Learning as a learning model to improve students' ability to think critically.
\end{abstract}

Keywords: critical thinking; Problem Based Learning; economic learning 


\section{PENDAHULUAN}

Kegiatan pembelajaran merupakan aktivitas komunikasi interaktif pada lingkungan belajar yang dilakukan oleh peserta didik dengan tenaga pendidik maupun sumber belajar. Aktivitas pembelajaran yang terjadi bertujuan untuk membimbing peserta didik mempelajari suatu materi pelajaran serta mengembangkan kemampuan yang dimiliki. Pelaksanaan kegiatan pembelajaran disesuaikan dengan kurikulum yang berlaku.

Kurikulum 2013 yang berlaku saat ini merupakan upaya pemerintah dalam meningkatkan mutu pembelajaran di Indonesia. Sistem pembelajaran dalam kurikulum 2013 melalui pendekatan saintifik yaitu dengan mengamati suatu objek, menanya, mengumpulkan data, menalar, dan mengasosiasi. Menjadikan peserta didik yang kreatif, kritis, dan berkarakter melalui sistem kurikulum 2013 akan efektif jika dilakukan melalui pendekatan saintifik dalam kegiatan pembelajaran (Sholikha, 2013). Pemberlakuan kurikulum 2013 di Indonesia bermaksud untuk mengembangkan kemampuan peserta didik agar lebih kritis dalam berpikir dan mengambangkan pengalaman belajar peserta didik.

Beberapa model pembelajaran yang dianggap efektif dalam kurikulum 2013, diantaranya Discovery Learning, Problem Based Learning dan Project Based Learning, Masing-masing model tersebut memiliki kelebihan dan kekurangan sehingga penerapan dalam pembelajaran harus memperhatikan beberapa hal misalnya, karakteristik peserta didik, sarana dan prasarana pembelajaran, materi belajar serta kemampuan guru mengajar.

Ketepatan dalam pemiliham model dalam pembelajaran akan membantu merealisasikan tujuan pembelajaran yang sudah ditetapkan dalam kurikulum. Guru berperan penting dalam pemilihan model pembelajaran. Guru dituntut untuk mampu mendesain model dalam pembelajaran yang disesuaikan dengan karakteristik peserta didik, materi pelajaran, kompetensi dasar yang harus dimiliki peserta didik serta fasilitas yang tersedia pada lingkungan belajar. Guru harus selalu kreatif mendesain model dalam pembelajaran agar peserta didik tertarik dan antusias mengikuti setiap kegiatan dalam pembelajaran sehingga materi yang disampaikan akan lebih mudah dipahami dan menjadikan pembelajaran akan lebih bermakna. 
Didapat informasi dari wawancara awal dengan guru ekonomi kelas XI IPA 2 SMA Negeri 1 Dagangan yaitu bahwa kemampuan peserta didik dalam menganalisis kasus-kasus pada materi ekonomi masih kurang. Peserta didik masih merasa kebingungan dalam menentukan inti permasalahan dalam suatu kasus sehingga berdampak pada kesulitan menganalisis dan menyelesaikan kasus yang ada. Selain itu, peserta didik juga kurang aktif mencari sumber referensi dalam memecahkan kasuskasus ekonomi. Peserta didik masih mengandalkan penjelasan dari guru serta buku pelajaran yang dimiliki.

Model pembelajaran yang digunakan guru mata pelajaran ekonomi selama ini belum mampu mengaktifkan peserta didik untuk mencari berbagai referensi yang relevan dengan materi yang dibahas. Rasa ingin tahu dan kemampuan berpikir peserta didik dalam menganalisis dan memecahkan kasus yang berkaitan dengan materi ekonomi sangat kurang, sehingga hasil belajar belum mencapai target yang ditetapkan. Peserta didik membutuhkan bimbingan dan arahan dalam mengembangkan pikiran kritis sehingga mampu menciptakan ide dan solusi dalam penyelesaian kasus ekonomi.

Upaya yang dapat dilakukan untuk melatih kompetensi peserta didik dalam menganalisis dan kritis dalam berpikir yaitu dengan penerapan model inovatif dalam pembelajaran yang mampu menjadikan peserta didik lebih aktif dan responsif dalam setiap kegiatan pembelajaran. Problem Based Learning (PBL) merupakan salah satu model pembelajaran yang mengharuskan peserta didik untuk aktif berpartisipasi dalam kegiatan pembelajaran. Pembelajaran melalui PBL dapat mendukung pendekatan saintifik pada kurikulum 2013 (Yuvica, Khaerudin, \& Wiraning F, 2015). Hasil penelitian Sofyan \& Komariah (2016) menyatakan bahwa mayoritas guru setuju jika penerapan PBL dilakukan pada setiap mata pelajaran dalam implementasi kurikulum 2013 karena terbukti meningkatkan keterampilan soft skills dan hard skills dari peserta didik. Pembelajaran dengan PBL efektif dalam mengembangkan kompetensi peserta didik dalam berpikir kritis (Aziz, Ahyan, \& Fauzi, 2016; Noer \& Gunowibowo, 2018; Said \& Azhar, 2020)

Model PBL melatih peserta didik untuk kritis dalam berpikir dan meningkatkan keterampilan dalam menganalisis masalah dan mencari solusinya. Dalam pembelajaran dengan PBL, peserta didik akan diberi suatu kasus yang sering terjadi dan ditemui dalam 
kehidupan nyata dan berkaitan dengan materi yang dipelajari. Peserta didik melalui pemikiran yang kritis dituntut untuk menganalisis kasus dan mencari solusi yang tepat untuk menyelesaikan kasus tersebut. Model PBL mengharuskan peserta didik berpartisipasi aktif dalam memecahkan masalah sehingga memungkinkan semua peserta didik terlibat dalam kegiatan pembelajaran serta meningkatkan rasa ingin tahu dari peserta didik terhadap permasalahan nyata yang ada dilingkungan sekitar.

Berdasarkan penjelasan tersebut, maka kegiatan pengabdian masyarakat ini dilaksanakan dengan melatih peserta didik agar lebih kritis dalam berpikir terhadap suatu masalah melalui PBL. Harapannya dengan penerapan PBL dalam pembelajaran dapat menarik perhatian peserta didik untuk meningkatkan motivasi belajar, rasa ingin tahu, partisipasi dan berpikir kritis dalam setiap kegiatan sehingga pembelajaran menjadi interaktif dan tercapainya tujuan pembelajaran.

\section{METODE}

Kegiatan pengabdian masyarakat dilakukan selama satu hari dengan peserta kegiatan yaitu peserta didik kelas XI IPA 2 pada SMA Negeri 1 Dagangan sejumlah 29 orang. Sebelum pelaksanaan kegiatan, tim pengabdian masyarakat terlebih dahulu melakukan wawancara kepada guru ekonomi terkait permasalah dalam kegiatan pembelajaran, kemudian guru ekonomi bersama tim pengabdian masyarakat menyusun kegiatan yang berfokus pada peningkatan kompetensi peserta didik dalam berpikir kritis pada kegiatan pembelajaran ekonomi melalui PBL. Langkah-langkah pelaksanaan kegiatan meliputi orientasi peserta didik pada masalah, mengorganisasi peserta didik, membimbing peserta didik dalam berpikir kritis terhadap masalah, membimbing peserta didik melakukan analisis masalah dan pemecahkan masalah, mengevaluasi kegiatan secara bersama-sama sebagai bahan perbaikan kegiatan selanjutnya.

Indikator keberhasilan kegiatan pengabdian masyarakat ditinjau dari sejauh mana kemampuan peserta didik dalam berpikir kritis setelah dilaksanakannya kegiatan pembelajaran melalui model PBL. Penilaian terhadap kemampuan peserta didik dalam berpikir kritis melalui tes dengan indikator yang dikembangkan dari penelitian (Noer \& Gunowibowo, 2018) meliputi identifikasi masalah, strategi dan teknik penyelesaian masalah, serta pembuatan kesimpulan, 


\section{HASIL DAN PEMBAHASAN}

Kegiatan pembelajaran mata pelajaran ekonomi dengan model PBL diikuti oleh para peserta didik kelas XI IPA 2 sejumlah 29 orang. Kegiatan pembelajaran terlaksana dengan baik, lancar dan memperoleh hasil sesuai harapan. Selama kegiatan berlangsung, terlihat semangat peserta didik dalam berpartisipasi pada setiap kegiatan pembelajaran. Tidak terlihat peserta didik yang mondar-mandir izin keluar kelas, asyik mengobrol sendiri dengan temannya, dan tidur di kelas. Semua peserta didik menyimak dan mengikuti kegiatan pembelajaran dengan tertib dan tenang.

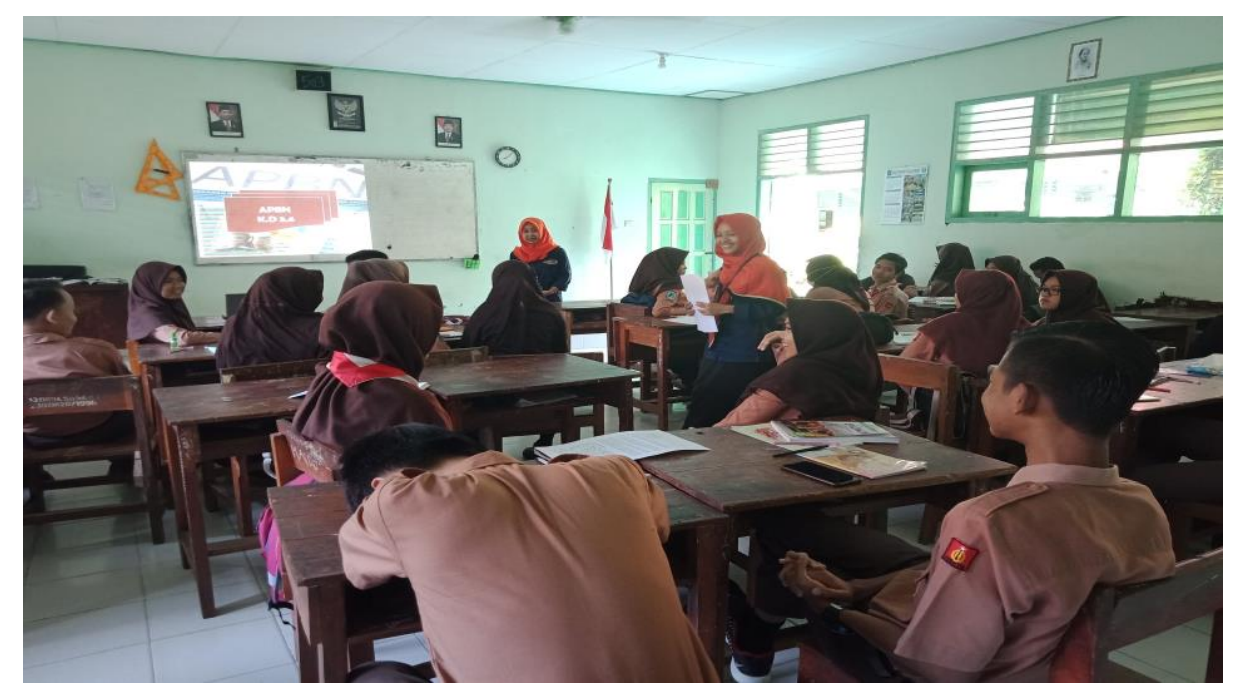

Gambar 1. Proses Penyampaian Materi Oleh Tim Pengabdian Masyarakat

Hasil pengamatan memperlihatkan bahwa peserta didik merespon positif pada kegiatan pembelajaran ekonomi dengan topik Anggaran Pendapatan dan Belanja Negara (APBN). Peserta didik juga terlihat aktif berpartisipasi dalam setiap kegiatan pembelajaran, terbukti dari banyaknya peserta didik yang aktif menanggapi dengan pertanyaan maupun memberi jawaban atas pertanyaan yang diberikan oleh tim pengabdian masyarakat. Tingginya Rasa ingin tahu peserta didik juga terlihat dari semangat peserta didik dalam mencari berbagai informasi dan referensi untuk menyelesaikan kasus yang diberikan melalui internet dan beberapa buku pelajaran. 


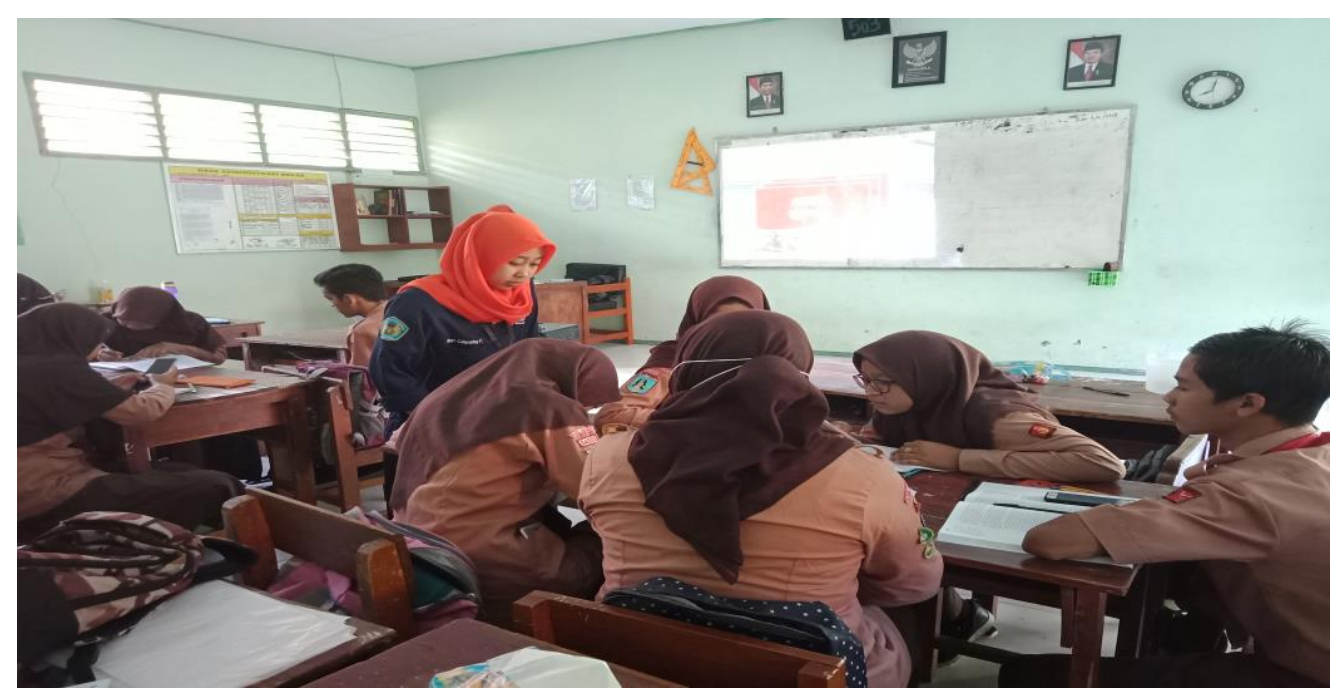

Gambar 2. Antusias Peserta Didik Mencari Referensi Melalui Buku dan Internet

Hasil analisis dan solusi yang disampaikan oleh peserta didik atas kasus yang diberikan sudah sesuai dengan harapan. Peserta didik juga saling menanggapi hasil diskusi dari kelompok yang berbeda. Kompetensi peserta didik dalam berpikir secara kritis yang ditinjau dari identifikasi masalah, strategi dan teknik penyelesaian masalah, serta pembuatan kesimpulan menunjukkan nilai rata-rata 85,08.

Tabel 1. Hasil Ketercapaian Indikator Berpikir Kritis

\begin{tabular}{clc}
\hline No & \multicolumn{1}{c}{ Indikator } & Nilai Rata-Rata \\
\hline 1 & Identifikasi masalah & 82,41 \\
2 & $\begin{array}{l}\text { Strategi dan teknik penyelesaian } \\
\text { masalah }\end{array}$ & 85,34 \\
3 & Pembuatan kesimpulan & 87,48 \\
\hline \multicolumn{1}{c}{ Total } & $\mathbf{8 5 , 0 8}$ \\
\hline
\end{tabular}

Hasil pemikiran kritis dari peserta didik dalam menghadapi suatu kasus atau masalah melalui model pembelajaran PBL yang dilihat dari ketercapaian masing-masing indikator masuk dalam kategori baik. Peserta didik awalnya mengalami kendala ketika harus memahami kasus atau masalah yang diberikan, tetapi dengan bimbingan dan arahan dari tim pengabdian masyarakat menjadikan peserta didik mampu mengindentifikasi masalah yang ada. Kemudian kegiatan dalam penentuan stategi dan 
teknik yang digunakan untuk menyelesaikan masalah sudah mulai dipahami oleh peserta didik sehingga mampu memberikan kesimpulan dalam penyelesaian masalah atau kasus yang diberikan dengan tepat.

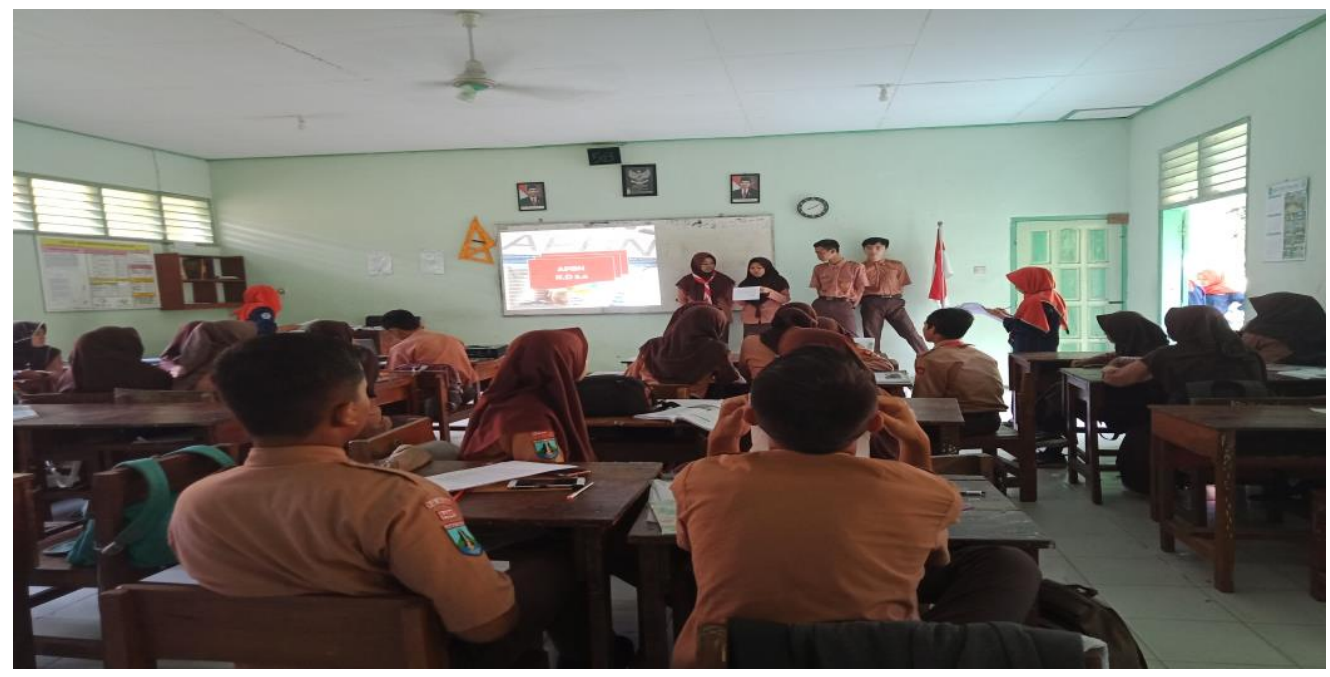

Gambar 3. Peserta Didik Menyampaikan Hasil Kesimpulan Di Depan Kelas

Hasil kegiatan pembelajaran melalui model PBL terbukti mampu mengembangkan kompetensi peserta didik dalam berpikir secara kritis sehingga permasalahan yang diberikan terkait APBN diselesaikan dengan baik. Harapan tim pengabdian masyarakat setelah kegiatan ini selesai, maka guru dan peserta didik dapat mempertahankan motivasi dan partisipasi dari peserta didik pada pembelajaran ekonomi dan menjadikan peserta didik memiliki kemampuan berpikir kritis terhadap kasus-kasus yang berkaitan dengan materi pelajaran maupun masalah dalam kehidupan nyata sehingga meningkatkan hasil belajar dan tujuan pembelajaran tercapai dengan lancar.

\section{SIMPULAN DAN SARAN}

Simpulan yang diperoleh dari pelaksanaan kegiatan pembelajaran melalui PBL terbukti dapat mengembangkan kompetensi peserta didik dalam proses berpikir secara kritis. Melalui strategi serta teknik berpikir kritis, peserta didik mampu mengidentifikasi masalah, menganalisis dan memberikan solusi pada kasus APBN. Kasus ekonomi yang berkaitan dengan APBN dapat diselesaikan peserta didik dengan baik dan sesuai dengan tujuan pembelajaran. Selama kegiatan berlangsung terlihat peserta didik antusias dalam 
mengikuti pembelajaran serta mengerjakan tugas sesuai petunjuk secara tertib dan tepat waktu.

Saran setelah adanya kegiatan pengabdian masyarakat ini yaitu guru diharapkan lebih inovatif dalam kegiatan proses pembelajaran. Dengan menggunakan metode inovatif maka akan meningkatkan motivasi dan partisipasi peserta didik sehingga memperlancar kegiatan pembelajaran dan tercapainya tujuan pembelajaran.

\section{UCAPAN TERIMA KASIH}

Tim pengabdian masyarakat berterima kasih kepada pihak sekolah SMA Negeri 1 Dagangan yang bersedia memberikan izin kegiatan serta membantu dalam kelancaran kegiatan. Ucapan terimakasih juga tim pengabdian masyarakat berikan kepada pengurus HIMADIKSI (Himpunan Mahasiswa Pendidikan Akuntansi) yang bersedia membantu selama kegiatan berlangsung.

\section{DAFTAR PUSTAKA}

Aziz, Abdul, Ahyan, Shahibul, \& Fauzi, Lalu Muhammad. (2016). Implementasi Model Problem Based Learning ( PBL ) Dalam Meningkatkan Kemampuan Berpikir Kritis Mahasiswa Melalui Lesson Study. Jurnal Elemen, 2(1), 83-91.

Noer, Sri Hastuti, \& Gunowibowo, Pentatito. (2018). Efektivitas Problem Based Learning Ditinjau Dari Kemampuan Berpikir Kritis Dan Representasi Matematis. Jurnal Penelitian Dan Pembelajaran Matematika, 11(2). https://doi.org/10.30870/jppm.v11i2.3751

Said, Sitaman, \& Azhar. (2020). Penerapan Model Problem Based Learning (PBL) untuk Meningkatkan Kemampuan Berpikir Kritis dan Hasil Belajar Siswa Kelas XI IPS 3 Pada Materi Ekonomi Di SMA Negeri 3 Kota Bima tahun Pelajaran 2019/2020. Jurnal PenKoMi : Kajian Pendidikan \& Ekonomi, 3(2), 75-85.

Sholikha, Siti Mazilatus. (2013). Penerapan Teknologi Informasi Dalam Pendekatan Saintifik Pada Mata Pelajaran Ekonomi. Prosiding Seminar Nasional 9 Mei 2015, $375-383$.

Sofyan, Herminarto, \& Komariah, Kokom. (2016). Pembelajaran Problem Based Learning Dalam Implementasi Kurikulum 2013 Di SMK. Jurnal Pendidikan Vokasi, 6(3), 260. https://doi.org/10.21831/jpv.v6i3.11275 
Yuvica, Khaerudin, Iyay Robia, \& Wiraning F, Nurul Senja. (2015). Penerapan Pendekatan Saintifik Melalui Model Problem Based Learning Terhadap Hasil Belajar Siswa Dalam Pembelajaran Ekonomi Pada Siswa SMA Kelas X (Studi Penelitian Eksperimen Semu Di SMA Negeri 1 Palimanan Kab. Cirebon). Edunomic, 3(2), 262-278. 